\title{
Comparison of Training Volumes in Different Elite Sportspersons According to Sex, Age, and Sport Practised
}

\author{
Jose M. Saavedra ${ }^{1}$, Sveinn Porgeirsson ${ }^{1}$, Hafrun Kristjansdottir ${ }^{1}$, Kristjan Halldorsson ${ }^{1}$, \\ Margret L. Guðmundsdottir ${ }^{1}$, Ingi P. Einarsson ${ }^{1}$
}

\begin{abstract}
Affiliations: 'Reykjavik University, School of Science and Engineering, Sports Science Department, Physical Activity, Physical Education, Health and Sport Research Centre (PAPESH), Reykjavik, Iceland

Correspondence: J. M. Saavedra, Reykjavik University, School of Science and Engineering, Physical Activity, Physical Education, Health and Sport Research Centre (PAPESH), Menntavegur 1, Nautholsvik, 101 Reykjavik, Iceland. E-mail: saavedra@ru.is
\end{abstract}

ABSTRACT Training is a complex process that depends, among other factors, on the intensity and volume of training. The objective of this study was to analyse the volume of training in several sports as a function of sex and age. The study sample consisted of 302 sportspersons (men, $n=132$; women, $n=170$ ) who participated in the $16^{\text {th }}$ Games of the Small States of Europe (1st to 6th June 2015) in representing nine countries. The subjects practised the following sports: artistic gymnastics, athletics, basketball, beach volleyball, golf, judo, shooting, swimming, table tennis, tennis, and volleyball, and were classified by sex, sport, and age (younger: $\leq 20$ years; intermediate: from 21 to 30 years; older: $\geq 31$ years). They responded to five questions about their training volume and the annual number of competitions in which they participated. A one-way ANOVA with a Bonferroni post hoc test was used to establish differences by sex, sport, and age group. Three-way ANOVAs (sex [men, women] $\times$ age [3 levels: younger, intermediate, older] $\times$ sport [11 sports]) were performed to determine any relationships between the variables. Neither interactions between the groups nor differences depending on sex were found in the training volumes, but the older the sportsperson, the lower the training volume (days per week, and total time per week). The sports with the greatest training volumes were artistic gymnastics and swimming, while those with the most competitions per year were basketball and volleyball.

KEY WORDS training load, training volume, performance, long-term plan, team sports

$@ M J S S M o n t e n e g r o$

TRAINING VOLUMES IN DIFFERENT ELITE SPORTSPERSONS

http://mjssm.me/?sekcija=article\&artid=161

\section{Introduction}

To reach the very peak in the world of sport performance, where medals and honours are earned by the smallest of margins, sportspersons seek every opportunity to gain a competitive edge. The successful development of an elite sportsperson requires years of careful planning and the manipulation of training variables to optimize his or her potential. To prepare for elite sport performance, sportspersons must undertake thousands of hours of training. The training process is dependent on many variables which coaches strive to structure and control to allow the sportspersons to achieve their goals (Saavedra, Escalante, García-Hermoso, \& Domínguez, 2013). Training is a complex process whose intensity and volume need to be quantified and controlled. These parameters in harmony with proper rest and recovery yield desired performance adaptations (Rietjens et al., 2005). The magnitude of a training load can be determined by the relationship between training intensity and volume (Laursen, 2010). The influence of training volume and intensity on performance has been extensively studied, but the relationship between these two parameters is complex. Intensity, on the one hand, has been described as a key component of team-sport performance and should be emphasized in training (Mujika, 2013), and a system of high-volume training, on the other, is characteristic of an elite sportsperson's preparation. Evidence of a sudden rise in training volume of elite sportspersons was seen in the almost doubling of swimmers' training volumes in preparation for the 1972 Olympic Games, and the improvement of world records in sports is generally

Received: January 112018 | Accepted after revision: January 242018 | First published online: September 012018

(C) 2018 by the author(s). License MSA, Podgorica, Montenegro. This article is an open access article distributed under the terms and conditions of the Creative Commons Attribution (CC BY).

Conflict of interest: None declared. 
recognized as reflecting higher training volumes (Ericsson, Frampe, \& Tesch-Römr, 1993). Although evidence has been found for decreasing volumes over the past decade, this can at least in part be explained by the increase in the number of competition days, advances in training methods, and enhanced technology (Issurin, 2008).

Adaptation to training volume and intensity can be different in men and women, producing different results. A recent study, for example, showed that women respond more strongly to two phases of an eight-week resistance training program than men do, and the authors conclude that the adaptation is sex-influenced (Ribeiro et al., 2015). Similarly, the values of maximum oxygen consumption in children and adolescents differ between the sexes (Armstrong, Tomkinson \& Ekelund, 2011). While in elite endurance sports (e.g., triathlon) there are no differences in training volume between men and women (Knechtle et al., 2015), younger and lower-level sportswomen (intercollegiate distance runners) train fewer miles per week and have fewer weekly sessions than their male counterparts do (Deaner, Lowen, Rogers, \& Saksa, 2015).

Age is another factor determining training volume. Sports participation is often encouraged and introduced early in children's lives as a way of maintaining a healthy lifestyle, of engaging in social interaction, and for enjoyment (Post et al., 2017). In elite adult sportspersons, training volume can reach 5 to 8 hours per day. In the last decade, training volumes have increased to 25-30 hours per week at their highest, eventually reaching elite status at around 4000 hours per year (Côté, Baker, \& Abernethy, 2007). However, in general terms, the increase in training volume is usually gradual until puberty, after which it increases substantially until adulthood when, in general, it is usually maintained to allow an increase in intensity (Bompa \& Haff, 2009). In this sense, different models of long-term sportsperson development have been proposed.

One model, initially developed in Canada (Balyi, 2001), points to different stages over a sportsperson's life: 1) active start (0-6 years old), 2) fundamental (men: 6-9 years old; women: 6-8 years old), 3) learn to train (men: 9-12 years old; women: 8-11 years old), 4) train to train (men: 12-16 years old; women: 11-15 years old), 5) train to compete (men: 16-23 years old; women: 15-21 years old), 6) train to win (men: >19 years old; women: $>18$ years old), and 7) active for life (physical activity sports). Sometimes, however, these stages are not respected, and there is early specialization in which volume and intensity are increased before puberty, which can lead to injuries (Post et al., 2017). Moreover, the age of peak sports performance usually coincides with training stages in which the volume is constant, although this may change from one sport to another. Thus, sports with high anaerobic demands, such as basketball, athletics, and table tennis, tend to have a peak age of around 22-28 years, whereas the more endurance- and technique-based events are at the older end of that continuum. In general, women peak at a younger age, e.g., in swimming at 18-22 years old, and in gymnastics, the most extreme, usually at around 14-18 years old (Stone, Stone, \& Sand, 2007). Furthermore, the age of peak competitive performance decreases linearly with increasing event duration for explosive power or sprint events, and increases linearly with increasing event duration for endurance events (Allen \& Hopkins, 2015).

With regard to sporting specialities, an adequate combination of volume and intensity is a prerequisite for efficient training. This combination is dependent on the duration and, therefore, on the metabolic requirements, of discipline-specific competition (Faude et al., 2008). Thus, for example, professional cyclists accumulate between 29,000 and 35,000 kilometres per year, while other specialities such as the 800-metre footrace have fewer hours of training (Laursen, 2010). Nonetheless, even within the same sport, for example, in swimming, the training volume can differ markedly between individuals of the same speciality and level (Saavedra et al., 2013). Moreover, there can be high training volumes in events that last just a little over two minutes, such as the 200-metre butterfly swim, in which the last Olympic women's champion, Mireia Belmonte, for the last Olympics accumulated nearly 200 weeks of $>80 \mathrm{~km}$ swum per week, 6 to 10 hours weekly of dryland training, and 12 to 14 weeks of altitude training per year (Mujika, 2017). In this context, the objective of the present study was to analyse the volume of training in various sports as a function of sex and age.

\section{Methods}

Subjects

A total of 653 sportspersons were invited to participate in this study through the collaboration of National Olympic and Sports Association of Iceland (Itrotta- og Olympiusamband Islands) (ISI). The final sample consisted of 302 sportspersons (men, $n=132$; women, $n=170$ ) who participated in the 16th Games of the Small States of Europe (1st to 6th June 2015) in the representation of nine countries: Andorra $(n=25)$, Cyprus ( $n=13)$, Iceland $(n=76)$, Liechtenstein $(n=22)$, Luxembourg $(n=51)$, Malta $(n=16)$, Monaco $(n=51)$, Montenegro $(n=18)$, and San Marino $(n=30)$. The subjects participated in eleven sports: artistic gymnastics $(n=18)$, athletics $(n=40)$, basketball $(n=56)$, beach volleyball $(n=13)$, golf $(n=5)$, judo $(n=20)$, shooting $(n=$ $11)$, swimming $(n=52)$, table tennis $(n=11)$, tennis $(n=7)$, and volleyball $(n=63)$. They were classified by sex, sport, and age (younger: $\leq 20$ years old; intermediate: between 21 and 30 years; older: $\geq 31$ years old), and completed an informed consent form. The study was approved by the Ethics Committee of the National Bioethics Committee of the Government of Iceland and followed the principles of the Declaration of Helsinki.

\section{Instrument}

The sportspersons responded to a short questionnaire (Saavedra, Escalante \& Rodríguez, 2010) about their volume of training and competition: 1) How many years have you been training? 2) How many days a week do you train? 3) How many hours a week do you train? 4) How many hours does your training session last? and 5) 
How many competitions do you have in a year?

Procedure

Initially, the researchers contacted the Olympic Committee of the country that organized the games to explain the project. Subsequently, they contacted the National Olympic Committees to explain the study. Informed consent and questionnaires were filled out by each participant before the competition. Both the consent and the questionnaire was presented in the official language of each country.

\section{Data analysis}

The normality and homoskedasticity of the distributions were tested using the Kolmogorov-Smirnov and Levene tests, respectively. Basic descriptive statistics (mean and standard deviation) were used to characterize the sample. A one-way ANOVA with a Bonferroni post hoc test was used to establish differences by sex, sport, and age group. Three-way ANOVAs (sex [men, women] $\times$ age [3 levels: younger, intermediate, older] $\times$ sport [11 sports]) were performed to determine the relationships between the variables. A $p$-value $<0.05$ was considered to be statistically significant. All analyses were performed using the computer software Statistical Package for Social Sciences (SPSS) version 21.0.

\section{Results}

Table 1 presents the results of the one-way ANOVA according to the sex. Only the variable "How many years have you been training?" presented differences between men and women.

TABLE 1 Means and standard deviations of responses to training volume questions, and one-way ANOVA as a function of sex.

\begin{tabular}{lcccc} 
& Men $(\boldsymbol{n}=\mathbf{1 3 2})$ & Women $(\boldsymbol{n}=\mathbf{1 7 0})$ & $\boldsymbol{F}$ & $\boldsymbol{p}$ \\
\cline { 2 - 3 } & Mean (SD) & Mean (SD) & & \\
\hline How many years have you been training? & $10.88(2.00)$ & $10.38(2.42)$ & 3.726 & 0.045 \\
How many days a week do you train? & $5.00(1.4)$ & $5.19(1.18)$ & 1.637 & 0.202 \\
How many hours a week do you train? & $15.85(5.34)$ & $15.29(4.58)$ & 0.944 & 0.322 \\
How many hours does your training session last? & $2.38(0.61)$ & $2.52(0.81)$ & 2.850 & 0.092 \\
How many competitions do you have in a year? & $17.56(6.14)$ & $18.45(6.31)$ & 1.481 & 0.225 \\
\hline
\end{tabular}

Table 2 presents the results of the one-way ANOVA with Bonferroni post hoc test according to age. All variables except "How many competitions do you have in a year?" presented differences between age groups. The younger sportspersons train more days per week and more times per week than the intermediate group, who in turn train more than the older group. The duration of the session is longer for the younger than for the older sportspersons.

TABLE 2 Means and standard deviations of responses to training volume questions, and one-way ANOVA with Bonferroni post hoc test as a function of age.

\begin{tabular}{|c|c|c|c|c|c|c|}
\hline & $\begin{array}{l}\text { (a) Younger } \\
\text { ( } \leq 20 \text { years) } \\
(n=108)\end{array}$ & $\begin{array}{c}\text { (b) Intermediate } \\
\text { (21 to } 30 \text { years) } \\
(n=152)\end{array}$ & $\begin{array}{c}\text { (c) Older } \\
(\geq 31 \text { years }) \\
(n=42)\end{array}$ & $\boldsymbol{F}$ & $\boldsymbol{p}$ & Differences \\
\hline & Mean (SD) & Mean (SD) & Mean (SD) & & & \\
\hline How many years have you been training? & $9.59(2.53)$ & $10.97(1.92)$ & $11.65(1.55)$ & 18.551 & $<0.001$ & $a, b<c$ \\
\hline How many days a week do you train? & $5.54(1.11)$ & $5.04(1.27)$ & $4.31(1.34)$ & 16.836 & $<0.001$ & $a>b>c$ \\
\hline How many hours a week do you train? & $16.89(4.80)$ & $15.40(4.92)$ & $12.87(4.10)$ & 11.796 & $<0.001$ & $a>b>c$ \\
\hline How many hours does your training session last? & $2.59(0.79)$ & $2.43(0.72)$ & $2.27(0.54)$ & 3.450 & 0.033 & $a>c$ \\
\hline How many competitions do you have in a year? & $17.41(6.05)$ & $18.63(6.31)$ & $17.80(6.40)$ & 1.192 & 0.305 & - \\
\hline
\end{tabular}

Table 3 shows the results of the one-way ANOVA with Bonferroni post hoc test according to the sport. All the variables showed differences. Artistic gymnastics, athletics, and swimming are the sports that involve the most days of training. Artistic gymnastics and swimming have the most training time per week, and artistic gymnastics and shooting have the longest training sessions. Finally, the team sports (basketball and volleyball) have more competitions per year than the other sports do.

There were no significant differences with respect to interactions (sex $\times$ age $\times$ sport) in any question: "How many years have you been training?" ( $F=.163, p=.999)$, "How many days a week have you been training?" $(\mathrm{F}=.967, \mathrm{p}=.478)$, "How many hours a week do you train?" $(F=1.252, p=.255)$, "How many hours does your training session last?" $(F=1.582, p=.106)$, “How many competitions do you have in a year?" $(F=1.903, p=.060)$. 
TABLE 3 Means and standard deviations of responses to training volume questions, and one-way ANOVA with Bonferroni post hoc test as a function of the sport

\begin{tabular}{|c|c|c|c|c|c|c|c|c|c|c|c|c|c|c|}
\hline & $\begin{array}{c}(a) \\
\text { Artistic } \\
\text { gymnastics } \\
(n=18)\end{array}$ & $\begin{array}{c}\text { (b) } \\
\text { Athletics } \\
(n=48)\end{array}$ & $\begin{array}{c}\text { (c) } \\
\text { Basketball } \\
(n=56)\end{array}$ & $\begin{array}{c}\text { (d) } \\
\text { Beach } \\
\text { volleyball } \\
(n=13)\end{array}$ & $\begin{array}{c}\text { (e) } \\
\text { Golf } \\
(n=5)\end{array}$ & $\begin{array}{c}\text { (f) } \\
\text { Judo } \\
(n=20)\end{array}$ & $\begin{array}{c}\text { (g) } \\
\text { Shooting } \\
(n=11)\end{array}$ & $\begin{array}{c}\text { (h) } \\
\text { Swimming } \\
(n=52)\end{array}$ & $\begin{array}{c}\text { (i) } \\
\text { Table tennis } \\
(n=11)\end{array}$ & $\begin{array}{c}(j) \\
\text { Tennis } \\
(n=7)\end{array}$ & $\begin{array}{c}(k) \\
\text { Volleyball } \\
(n=63)\end{array}$ & $\mathbf{F}$ & $\mathbf{p}$ & Differences \\
\hline & $\begin{array}{l}\text { Mean } \\
\text { (SD) }\end{array}$ & $\begin{array}{l}\text { Mean } \\
\text { (SD) }\end{array}$ & $\begin{array}{l}\text { Mean } \\
\text { (SD) }\end{array}$ & $\begin{array}{l}\text { Mean } \\
\text { (SD) }\end{array}$ & $\begin{array}{c}\text { Mean } \\
\text { (SD) }\end{array}$ & $\begin{array}{l}\text { Mean } \\
\text { (SD) }\end{array}$ & $\begin{array}{c}\text { Mean } \\
\text { (SD) }\end{array}$ & $\begin{array}{l}\text { Mean } \\
\text { (SD) }\end{array}$ & $\begin{array}{l}\text { Mean } \\
\text { (SD) }\end{array}$ & $\begin{array}{l}\text { Mean } \\
\text { (SD) }\end{array}$ & $\begin{array}{l}\text { Mean } \\
\text { (SD) }\end{array}$ & & & \\
\hline $\begin{array}{l}\text { How many years } \\
\text { have you been } \\
\text { training? }\end{array}$ & $\begin{array}{l}11.19 \\
(1.17)\end{array}$ & $\begin{array}{c}9.93 \\
(2.89)\end{array}$ & $\begin{array}{l}11.61 \\
(1.17)\end{array}$ & $\begin{array}{c}9.09 \\
(2.43)\end{array}$ & $\begin{array}{l}10.75 \\
(1.89)\end{array}$ & $\begin{array}{l}11.42 \\
(1.21)\end{array}$ & $\begin{array}{c}9.91 \\
(4.37)\end{array}$ & $\begin{array}{l}12.13 \\
(2.06)\end{array}$ & $\begin{array}{l}10.91 \\
(2.30)\end{array}$ & $\begin{array}{l}10.71 \\
(2.56)\end{array}$ & $\begin{array}{l}10.68 \\
(2.00)\end{array}$ & 3.176 & 0.001 & $b, d<c<h$ \\
\hline $\begin{array}{l}\text { How many days } \\
\text { a week do you } \\
\text { train? }\end{array}$ & $\begin{array}{l}5.57 \\
(0.75)\end{array}$ & $\begin{array}{c}5.48 \\
(1.11)\end{array}$ & $\begin{array}{c}4.89 \\
(1.29)\end{array}$ & $\begin{array}{c}4.23 \\
(1.17)\end{array}$ & $\begin{array}{c}3.25 \\
(0.50)\end{array}$ & $\begin{array}{l}5.05 \\
(1.32)\end{array}$ & $\begin{array}{c}4.10 \\
(1.20)\end{array}$ & $\begin{array}{c}6.17 \\
(0.61)\end{array}$ & $\begin{array}{c}3.60 \\
(0.97)\end{array}$ & $\begin{array}{l}5.57 \\
(0.96)\end{array}$ & $\begin{array}{c}4.69 \\
(1.27)\end{array}$ & 11.732 & $<0.001$ & $\begin{array}{c}a>c, e, g, i \\
b>d, e, g, i, k \\
h>c, d, e, f, g, i, k f, j>i\end{array}$ \\
\hline $\begin{array}{l}\text { How many hours } \\
\text { a week do you } \\
\text { train? }\end{array}$ & $\begin{array}{l}20.07 \\
(4.07)\end{array}$ & $\begin{array}{l}15.26 \\
(4.56)\end{array}$ & $\begin{array}{l}14.45 \\
(4.17)\end{array}$ & $\begin{array}{l}13.35 \\
(3.92)\end{array}$ & $\begin{array}{l}12.25 \\
(1.50)\end{array}$ & $\begin{array}{l}14.53 \\
(4.13)\end{array}$ & $\begin{array}{l}13.20 \\
(4.87)\end{array}$ & $\begin{array}{l}20.13 \\
(4.17)\end{array}$ & $\begin{array}{l}11.95 \\
(3.76)\end{array}$ & $\begin{array}{l}18.79 \\
(5.82)\end{array}$ & $\begin{array}{l}13.17 \\
(3.56)\end{array}$ & 13.838 & $<0.001$ & $\begin{array}{c}a, h>b, c, d . e . f . g . i . k \\
j>i, k\end{array}$ \\
\hline $\begin{array}{l}\text { How many } \\
\text { hours does your } \\
\text { training session } \\
\text { last? }\end{array}$ & $\begin{array}{c}3.24 \\
(0.60)\end{array}$ & $\begin{array}{c}2.26 \\
(0.44)\end{array}$ & $\begin{array}{c}2.06 \\
(0.23)\end{array}$ & $\begin{array}{c}3.31 \\
(0.48)\end{array}$ & $\begin{array}{l}2.50 \\
(0.58)\end{array}$ & $\begin{array}{c}2.35 \\
(0.68)\end{array}$ & $\begin{array}{c}3.00 \\
(1.25)\end{array}$ & $\begin{array}{c}2.70 \\
(0.82)\end{array}$ & $\begin{array}{c}2.36 \\
(0.50)\end{array}$ & $\begin{array}{c}3.14 \\
(0.90)\end{array}$ & $\begin{array}{c}2.53 \\
(0.82)\end{array}$ & 6.492 & $<0.001$ & $a>b, c, f, k b<g, h, j, k$ \\
\hline $\begin{array}{l}\text { How many } \\
\text { competitions } \\
\text { do you have in a } \\
\text { year? }\end{array}$ & $\begin{array}{l}10.57 \\
(1.21)\end{array}$ & $\begin{array}{l}14.95 \\
(5.16)\end{array}$ & $\begin{array}{l}23.29 \\
(4.75)\end{array}$ & $\begin{array}{l}17.04 \\
(6.24)\end{array}$ & $\begin{array}{l}18.25 \\
(7.89)\end{array}$ & $\begin{array}{l}14.20 \\
(5.00)\end{array}$ & $\begin{array}{l}14.75 \\
(5.33)\end{array}$ & $\begin{array}{l}17.38 \\
(5.82)\end{array}$ & $\begin{array}{l}16.27 \\
(7.03)\end{array}$ & $\begin{array}{l}20.21 \\
(5.52)\end{array}$ & $\begin{array}{l}21.29 \\
(4.23)\end{array}$ & 16.668 & $<0.001$ & $\begin{array}{c}a<c, k c>b, d, f, g, h . i \\
k>b, f, g, h\end{array}$ \\
\hline
\end{tabular}

\section{Discussion}

This study has analysed the training volume of more than 300 elite sportspersons based on sex, age, and sport practised. It offers the first comparison of participation in the same sport championship, in this case, the Games of the Small States of Europe. This championship is held every two years, and only countries with fewer than 1,000,000 inhabitants can participate. In general, the study has shown that there are no differences in training volume between men and women, but the older the sportsperson, the fewer the days per week and the less total time per week they train. The sports with the greatest training volumes were artistic gymnastics and swimming, and those with the most competitions annually were basketball and volleyball. These results suggest that training volume does not depend on sex but does depend on age and the sport practised. This seems to indicate the need for the individualization of training volume according to these last two aspects. This concurs with the International Olympic Committee consensus statement on training load in sport and injury risk (Soligard et al., 2016), indicating that training volume should always be monitored individually.

There were no differences by sex in the variables related to training volume except for the variable "How many years have you been training?" (men: $10.88 \pm 2.00$ years; women: $10.38 \pm 2.42$ years; $F=3.726 ; p=.045$ ). Perhaps this is because the male participants were older on average than the females ( 26.54 years versus 23.89 years, respectively). These results do not concur, however, with the "long-term athlete development model" (Balyi, 2001), which showed that women should start the training stages before men: train to train, train to compete, and train to win. With respect to age, the younger sportspersons ( $<20$ years old) had more training days and greater total training time per week than those of 21 to 30 years in age, and these in turn more than those of 31 years in age or older. Young sportspersons take on more generalized training than older sportspersons who concentrate more on sport-specific training aimed at maintaining performance levels for competition (Stone et al., 2007). However, this general training does not always entail longer training time. While at young ages training is usually focused on technique and aerobic content, in adulthood, training is usually focused on anaerobic content (Sweetenham, 2006). While the latter requires less time involving effort at high speeds, it also requires more recovery time, so that the total training time could be similar.

Analysing the sports disciplines, we observed that artistic gymnastics and swimming had the most sessions and total training time per week. The values found were lower than those reported in other studies (Saavedra et al., 2013; Silva \& Paiva, 2013). A weekly training time of more than 35 hours in artistic gymnastics has, however, been associated with poor sleep quality (Silva \& Paiva, 2013). The sports with longest training session durations were artistic gymnastics, tennis, and shooting. This could be because the first two of these sport specialities have high technical complexity, which means that they require a considerable recovery time between exercises, while shooting requires an extra time of concentration before each shot, which could lengthen the duration of its training sessions. Regarding the annual number of competitions, basketball and volleyball had the most (more than 21 competitions per year). That team sports reported more competition days was to be expected since these sports normally compete in a league format with multiple games, whereas individual sports 
usually enter a competition lasting a couple of days or more. Although basketball and volleyball competition management organisations develop more matches per year, it should be taken into consideration that the increase in the number of competitions per year could lead to an increase in the number of injuries (Soligard et al., 2016). In this sense, it would be interesting to identify the cut-off points for the maximum number of annual competitions for young and professional sportspersons (Schwellnus et al., 2016).

This study has various limitations. First, the level of the participants was heterogeneous. They all represented their different countries; some of them were at levels that would allow them to compete in World Championships or Olympic Games, while others were not at that level. Second, the distribution of the number of participants was not the same in all the sports. Third, Olympic and non-Olympic sports were compared with each other - a fact that could have influenced the training volumes that each of them implemented.

In conclusion, the study has shown that, in the sportspersons analysed, while their training volume is unrelated to their sex, it is related to their age. In particular, the older the sportsperson, the less their volume of training (training sessions per week and weekly training time). There are differences in training volume depending on the sport, with artistic gymnastics and swimming being the sports that have the greatest volumes. These results seem to reflect the need to prescribe the volume of training according to the sportsperson's age and the sport. Finally, the sports with the most competitions annually are those that use a league system: basketball and volleyball.

\section{Acknowledgements}

We gratefully acknowledge the collaboration of the National Olympic and Sports Association of Iceland (Íprótta- og Ólympíusamband Îslands) (ISI), and all Olympic Committees from Andorra, Cyprus, Liechtenstein, Luxembourg, Malta, Monaco, Montenegro and San Marino. Also, thanks to Ómar Friðriksson (input data in SPSS), Robert A. Chatwin, PhD (check English) and of all the subjects and their coaches who participated in the study.

\section{REFERENCES}

Allen, S.V. \& Hopkins, W.G. (2015). Age of peak competitive performance of elite athletes: A systematic review. Sports Medicine, 45(10), 1431-1441. doi: 10.1007/s40279-015-0354-3

Armstrong, N., Tomkinson, G.R. \& Ekelund, U. (2011). Aerobic fitness and its relationship to sport, exercise training and habitual physical activity during youth. British Journal of Sports Medicine, 45, 849-858. doi:10.1136/bjsports-2011-090200

Balyi, I. (2001). Sport system building and long-term athlete development in Canada. Coaches Report: The Official Publication of the Canadian Professional Coaches Association, 8(1), 25-28.

Bompa, T.O. \& Haff, G.G. (2009). Periodization: Theory and methodology of training. Champaign, Illinois (USA): Human Kinetics Publishers.

Côté, J., Baker, J., \& Abernethy, B. (2007). Practice and Play in the Development of Sport Expertise. In R. Eklund \& G. Tenenbaum (Eds.), Handbook of Sport Psychology (3. ed., pp. 184-202). Hoboken, NJ: Wiley.

Deaner, R.O., Lowen, A., Rogers, W. \& Saksa, E. (2015). Does the sex difference in competitiveness decrease in selective sub-populations? A test with intercollegiate distance runners. PeerJ 3:e884; doi: 0.7717/peerj.884. Retrieved April 28, 2017, from https://peerj.com/articles/884.pdf.

Ericsson, K. A., Krampe, R. T., \& Tesch-Römer, C. (1993). The Role of Deliberate Practice in the Acquisition of Expert Performance. Psychological Review, 100(3), 363-406. doi http://dx.doi.org/10.1037/0033295X.100.3.363

Faude, O., Meyer, T., Scharhag, J., Weins, F., Urhausen, A., \& Kindermann, W. (2008). Volume vs. Intensity in the Training of Competitive Swimmers. International Journal of Sports Medicine, 29(11), 906-912. doi: http://doi.org/10.1055/s-2008-1038377

Issurin, V. B. (2008). Block periodization versus traditional training theory: a review. Journal of Sports Medicine and Physical Fitness, 48(1), 65-75.

Knechtle, B., Knechtle, R., Stiefel, M., Zingg, M.A., Rosemann, T. \& Rüst, C.A. (2015). Variables that influence Ironman triathlon performance - what changed in the last 35 years? Open Access Journal of Sports Medicine 2015:6 277-290. doi: 10.2147/OAJSM.S85310

Laursen, P. B. (2010). Training for intense exercise performance: high-intensity or high-volume training?: High-intensity and high-volume training. Scandinavian Journal of Medicine and Science in Sports, 20, 1-10. doi: http://doi.org/10.1111/j.1600-0838.2010.01184.x

Mujika, I. (2013) The alphabet of Sport Science research starts with Q. International Journal of Sports Physiology and Performance, 8(5), 465-466.

Mujika, I. (2017). Winning the BIG medals. International Journal of Sports Physiology and Performance, 12, 273 -274. doi: https://doi.org/10.1123/IJSPP.2017-0016

Post, E.G., Trigsted, S.M., Riekena, J.W., Hetzel, S., McGuine, T.A., Brooks, M.A., Bell, D.R. (2017). The association of sport specialization and training volume with injury history in youth athletes. American Journal of Sports Medicine, 45(6):1405-1412. doi: 10.1177/0363546517690848

Ribeiro, A. S., Avelar, A., Schoenfeld, B. J., Fleck, S. J., Souza, M. F., Padilha, C. S., \& Cyrino, E. S. (2015). Analysis of the training load during a hypertrophy-type resistance training programme in men and 
women. European Journal of Sport Science, 15(4), 256-264. doi: http://doi.org/10.1080/17461391.2014. 940559

Rietjens, G. J. W. M., Kuipers, H., Adam, J. J., Saris, W. H. M., van Breda, E., van Hamont, D., \& Keizer, H. A. (2005). Physiological, Biochemical and Psychological Markers of Strenuous Training-Induced Fatigue. International Journal of Sports Medicine, 26(01/02), 16-26. doi: http://doi.org/10.1055/s-2004-817914

Saavedra, J.M., Escalante, Y., Rodríguez, F.A. (2010). A multivariate analysis of performance in young swimmers. Pediatric Exercise Science, 22: 135-151.

Saavedra, J. M., Escalante, Y., Garcia-Hermoso, A., \& Dominguez, A. M. (2013). Training volume and performance of young Spanish national and international level swimmers. South African Journal for Research in Sport, Physical Education and Recreation, 35(2), 163-172.

Schwellnus, M., Soligard, T., Alonso, J.M., Bahr, R., Clarsen, B., Dijkstra, H.P., ... Engebretsen, L. (2016). How much is too much? (Part 2). International Olympic Committee consensus statement on load in sport and risk of illness. British Journal of Sports Medicine, 50:1043-1052. doi:10.1136/bjsports-2016-096572

Silva, M. \& Paiva, T. (2013). Sleep, precompetitive stress and achievements in young performance athletes. Sleep Medicine 14S: e239-e317. doi: https://doi.org/10.1016/j.sleep.2013.11.656

Soligard, T., Schwellnus, M., Alonso, J.M., Bahr, R., Clarsen, B., Dijkstra, H.P., Gabbett, T.,... Engebretsen, L. (2016). How much is too much? (Part 1). International Olympic Committee consensus statement on load in sport and risk of injury. British Journal of Sports Medicine, 50:1030-1041. doi:10.1136/ bjsports-2016-096581

Stone, M. H., Stone, M., \& Sands, B. (2007). Principles and practice of resistance training. Champaign, IL: Human Kinetics.

Sweetenham B. (2006). Break point volume. American Swimming Magazine, 23: 34-36. 